\title{
Shallow kelp canopies mediate macroalgal composition: effects on the distribution and abundance of Corynactis californica (Corallimorpharia)
}

\author{
Kathleen Morrow*, Robert Carpenter \\ Department of Biology, California State University, Northridge, California 91330, USA
}

\begin{abstract}
Competitive and facilitative interactions are common throughout the rocky subtidal and may be important when determining organism distribution and abundance. In this study, we used the corallimorpharian Corynactis californica to examine these relationships as they develop spatially and temporally between 2 kelp forest habitats. Sampling along Santa Catalina Island, California, USA, demonstrated that $C$. californica densities are up to 4 -fold greater under canopies of the stipitate kelp Eisenia arborea than in areas just outside the canopy. Stipitate kelp canopies can act as foundation species by modifying critical resources (e.g. light and flow) that mediate understory assemblages. It was determined that the understory algal community is $17 \%$ less dense and is distinguished by branching red algae, whereas the non-shaded community is characterized by dense stands of foliose and decumbent brown algae. This study quantified the relationship among benthic macroalgae and C. californica to determine whether macroalgae were negatively or positively affecting C. californica distributions. Permanent $25 \times 25 \mathrm{~cm}$ quadrats were established in both the canopy and open habitat, and understory algal biomass was manipulated with 3 treatments: (1) $100 \%$ removal; (2) thinning by $50 \%$; and (3) no removal (control). All treatments were censused and maintained monthly for $1 \mathrm{yr}$. C. californica abundance increased in the control treatments in both habitats, and to the greatest extent under $E$. arborea canopies, suggesting a positive interaction between understory macroalgae and $C$. californica. The results of this study indicate that $E$. arborea creates a unique habitat that differs in water flow, light attenuation, and in composition and density of macroalgae. The combination of these factors under the $E$. arborea canopy may support large aggregations of $C$. californica (up to $3200 \mathrm{~m}^{-2}$ ) in an otherwise sub-optimal habitat compared to subtidal vertical walls.
\end{abstract}

KEY WORDS: Eisenia arborea $\cdot$ Corynactis californica $\cdot$ Facilitation $\cdot$ Competition $\cdot$ Foundation Species · Macroalgae

Resale or republication not permitted without written consent of the publisher

\section{INTRODUCTION}

Understanding how species coexist while competing for one or more similar resources has been a continuing goal of ecologists (Hutchinson 1961, Connell \& Slayter 1977, Connolly \& Muko 2003). Niche overlap between species historically has implied negative impacts resulting in competition and/or competitive exclusion of one or more species. Over the past decade, research has highlighted the importance of positive (facilitative) as well as negative (competitive) interactions in structur- ing communities (Bruno et al. 2003). Through positive species interactions organisms may act in partnership, leading to competitive release and niche expansion. Moreover, the interplay of positive and negative associations has been addressed only recently and appears to have important influences on structuring plant and/or invertebrate assemblages (Callaway \& Walker 1997, Bertness et al. 1999, Travis et al. 2004).

Competition for space, light and food occurs frequently on horizontal surfaces in rocky reef communities because much of the available hard substratum is colo- 
nized by invertebrate and algal assemblages (Jackson 1977, Witman \& Dayton 2001). In particular, competition between invertebrates and macroalgae has been recognized as an important factor structuring the benthic community (Connell 1983, Witman \& Dayton 2001). This relationship has been a focus in studies of tropical coral reefs where an increased standing crop of macroalgae is suggested to out-compete corals leading to a phase-shift, in which corals are replaced by algae (Hughes 1994, Jompa \& McCook 2002, McManus \& Polsenberg 2004). It has been hypothesized that macroalgae affect invertebrates negatively via space evasion, overgrowth, and allelochemicals or indirectly by increasing sedimentation, acting as vectors of disease and/or inhibiting particle capture. For example, macroalgae inhibited the growth of the temperate coral Balanophyllia through thallus abrasion, which caused chronic retraction of the coral polyp and led to overgrowth of the exposed calyx by filamentous and encrusting coralline algae (Coyer et al. 1993). Conversely, large aggregations of anemones may out-compete macroalgae for available space (Taylor \& Littler 1982) or suppress algal growth by emitting allelochemicals (Bak \& Borsboom 1984). However, there is little direct experimental evidence that sessile invertebrates and algae do compete, and few studies have addressed the mechanisms of this interaction (McCook et al. 2001).

The present study quantifies the interactions between the corallimorpharian Corynactis californica and associated macroalgae. In general, most members of the Corallimorpharia (Cnidaria: Anthozoa) form polyps that do not contain intracellular photosynthesizing symbionts (LaJeunesse et al. 2004). Since C. californica is heterotrophic exclusively, it is possible to study the effects of contrasting algal assemblages on polyps between habitats exposed to high and low light regimes without the confounding effect of depleted symbiont efficiency due to shading. Although previous evidence supports a competitive relationship between macroalgae and suspension feeders (Littler \& Littler 1997, Jompa \& McCook 2002), recent literature has placed renewed attention on the importance of positive interactions (Callaway 1995, Bruno et al. 2003), as well as competition (Jackson 1977, Connell 1983) in structuring species assemblages.

The present study examines the relationships among invertebrates and understory macroalgae that may be mediated by the foundation species Eisenia arborea (Phaeophyta: Laminariales) at Santa Catalina Island, California, USA. We follow the general definition of a foundation species as a single species that defines much of the structure of the community by creating locally stable conditions for other species, and by modulating and stabilizing fundamental ecosystem processes (sensu Dayton 1972). E. arborea is a stipitate kelp that reaches heights of approximately $1 \mathrm{~m}$ and is characterized by a basal holdfast and thick upright stipe bearing 2 clusters of terminal blades (Abbott \& Hollenberg 1976). Macroalgae, invertebrates and fishes utilize kelp habitats as food, refuge from predators, and as a substratum for growth (Eckman et al. 1989, Allen et al. 2006). Kelp canopies influence light and water flow, which structure understory assemblages by altering food availability, gas exchange, sedimentation, thallus abrasion and photosynthetic efficiency (Kennelly 1987a,b, Witman \& Dayton 2001, Irving \& Connell 2002, 2006). Stipitate kelp in southern Australia, similar in structure to E. arborea, have been shown to create reproducible patterns in understory invertebrate and algal assemblages over large $(1000 \mathrm{~km})$ spatial scales (Kennelly 1989, Connell $2003 a, b)$. In this way, stipitate kelp forests act as foundation species similarly to other macrophyte canopies (e.g. Macrocystis, Thallassia) by mediating the availability of biotic and abiotic resources, and ultimately by stratifying rocky subtidal communities into 2 discrete habitats, herein referred to as 'canopy' and 'open' habitats (Dayton 1972) (Fig. 1). Some authors have referred to founda-

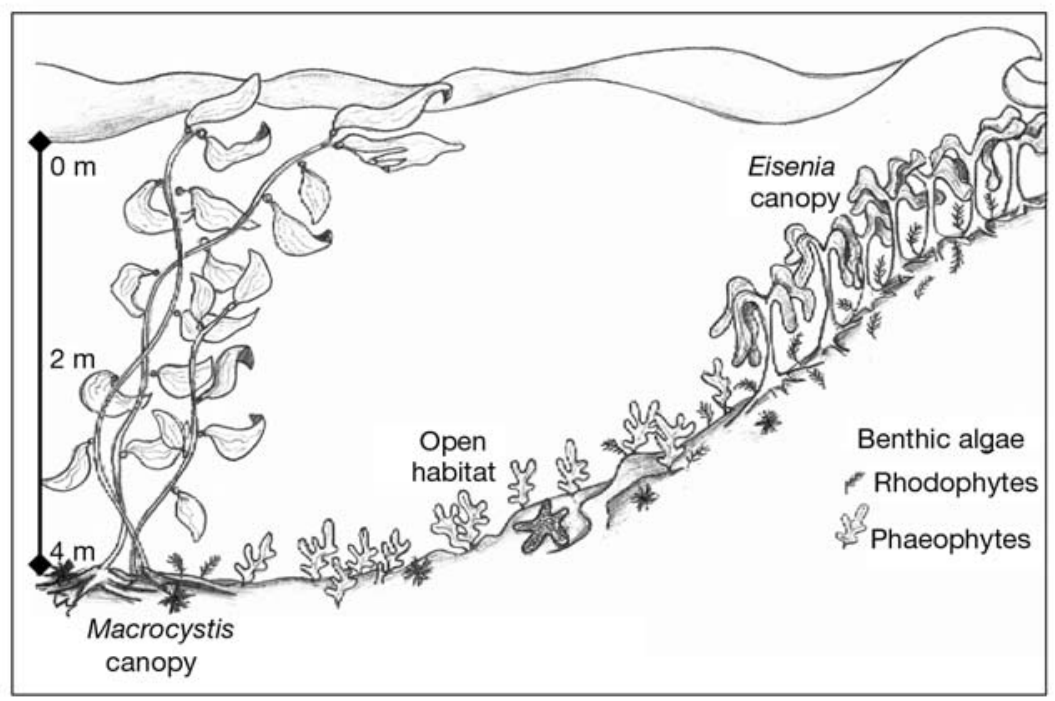

Fig. 1. Three habitat zones distinguished by the presence and absence of kelp canopies in the shallow subtidal at Santa Catalina Island, California, USA. Eisenia canopy: habitat identified by the presence of an E. arborea kelp canopy and a benthic community dominated by foliose rhodophytes and aggregations of Corynactis californica. Open habitat: between kelp canopies and distinguished by a benthic community dominated by foliose phaeophytes. Macrocystis canopy: beginning at approximately $5 \mathrm{~m}$, extending further to much greater depths and distinguished primarily by a $M$. pyrifera canopy as well as lower flow and light levels than the Eisenia canopy and open habitat 
tion species as a type of keystone species that should be considered a critical component of the ecosystem (Bruno \& Bertness 2001b). In the present study, distinct distributional patterns were observed among assemblages of benthic macroalgae and invertebrates found in $E$. arborea canopy versus open habitats.

Corynactis californica populations at Bird Rock, Santa Catalina Island, were used to quantify the relationship among invertebrate and algal assemblages under stipitate kelp canopies and in open exposed habitats (<5 m depth) (Fig. 1). Preliminary observations revealed that greater densities of $C$. californica polyps were found under canopies of Eisenia arborea than outside canopies. It was hypothesized that differences in the density of understory algae between the canopy and open habitat altered C. californica densities based on whether the interaction was facilitative or competitive (i.e. positive or negative). Furthermore, it was hypothesized that the understory algae, and not the E. arborea canopy, was the most significant factor responsible for a greater abundance of C. Californica polyps under canopies, because most direct effects of E. arborea would be negative or neutral (e.g. abrasion by thalli, shading) and would either lower the abundance of understory polyps or have no effect. The objectives of this study were to: (1) quantify the density of C. californica in each habitat; (2) quantify the abundance and type of understory algae in each habitat; and (3) determine the extent to which percent cover of understory algae in either canopy or open habitats affects C. californica abundance. It is important to note that higher densities of $C$. californica can be found on vertical rock walls devoid of any macroalgae. However, this study chose to focus on horizontal substrata where C. californica and algae are in direct contact, although this may be considered a sub-optimal habitat.

\section{MATERIALS AND METHODS}

Corallimorpharians are found on rocky reefs worldwide as solitary individuals or as clonal aggregations ranging from 400 to 2500 polyps $\mathrm{m}^{-2}$ on both horizontal and vertical substrata (Chadwick 1987, 1991, K. Morrow pers. obs.). Corynactis californica (Cnidaria: Anthozoa) is a common invertebrate found on hard substrata in kelp habitats and is the only species of corallimorpharian to occur along the west coast of North America, where it ranges from Washington to Baja, California (Chadwick 1987). We observed that polyps at Santa Catalina Island could reach a maximum pedal disc diameter of ca. $20 \mathrm{~mm}$ (pers. obs.). C. californica reproduces asexually by longitudinal fission and sexually with a seasonal cycle of oogenesis, spawning planktonic larvae from November through
January (Holts \& Beauchamp 1993). Compared to other scleractinian and actinarian Anthozoa, polyps of C. californica have a rapid rate of asexual reproduction, each producing a new polyp in less than $5 \mathrm{wk}$ and doubling in number in less than 2 mo (Chadwick 1987, Chadwick \& Adams 1991). In contrast, Astrangia, a local scleractinian, may only produce asexually 0.12 polyps $\mathrm{yr}^{-1}$ (Chadwick 1991) and the clonal anemone Anthopleura elegantissima may take over 2 yr to double in population size (Sebens 1982). C. Californica also aggressively defends substratum space by extruding mesenterial filaments that kill competitors, thus altering the settlement behavior of other benthic invertebrates and deterring potential predators (Chadwick 1987, 1991, Patton et al. 1991). However, Chadwick (1987) determined that C. californica did not extrude mesenterial filaments onto the red alga Rhodymenia pacifica or onto neighboring conspecifics. No other study has addressed the mechanisms involved in determining competitive boundaries between corallimorpharians and macroalgae, although they often are found in association.

The present study was completed using the facilities at the Wrigley Marine Science Center (WMSC) on Santa Catalina Island, California. The study site was located on the west end of Bird Rock, about $1 \mathrm{~km}$ from WMSC $\left(33^{\circ} 27^{\prime} \mathrm{N} 118^{\circ} 29^{\prime} \mathrm{W}\right)$ (Fig. 2). This site is characterized by a gradual slope with rocky outcrops, cobbles, and sand. The reef is stratified into 3 distinct benthic habitats by the stipitate kelp Eisenia arborea and the giant kelp Macrocystis pyrifera, ranging from 0 to $10 \mathrm{~m}$ depth (Fig. 1). The 2 study habitats were designated by the presence or absence of $E$. arborea found in the shallow subtidal zone ( 0 to $4 \mathrm{~m}$ depth). The E. arborea bed extends approximately $10 \mathrm{~m}$ horizontally from shore and runs parallel to Bird Rock for approximately $40 \mathrm{~m}$. Bird Rock is exposed to swells ranging from 1 to $3 \mathrm{~m}$ in height, and water velocities of 1 to $7 \mathrm{~m} \mathrm{~s}^{-1}$ seasonally, with the highest exposure during November through February (R. Carpenter unpubl. data).

The percent cover of understory macroalgae was estimated in $25 \mathrm{~cm} \times 25 \mathrm{~cm}\left(0.0625 \mathrm{~m}^{2}\right)$ quadrats $(\mathrm{n}=$ $30)$ that were placed haphazardly in both habitats during 6 sampling periods over 1 yr. Quadrats were subdivided into 25 squares (each representing $4 \%$ of the quadrat) and the macroalgal species dominating each subdivision was recorded. Macroalgae were allocated into 4 taxonomic groups loosely defined by morphology and represented by (1) foliose phaeophytes Colpomenia, Cystoseira, Dictyopteris, Dictyota, Halidrys, and Zonaria; (2) foliose/branching rhodophytes Chondracanthus, Gelidium, Laurencia, Plocamium and Pterocladiella; (3) articulated corallines Bossiella, Corallina, and Lithothrix; and (4) crustose coralline algae. 


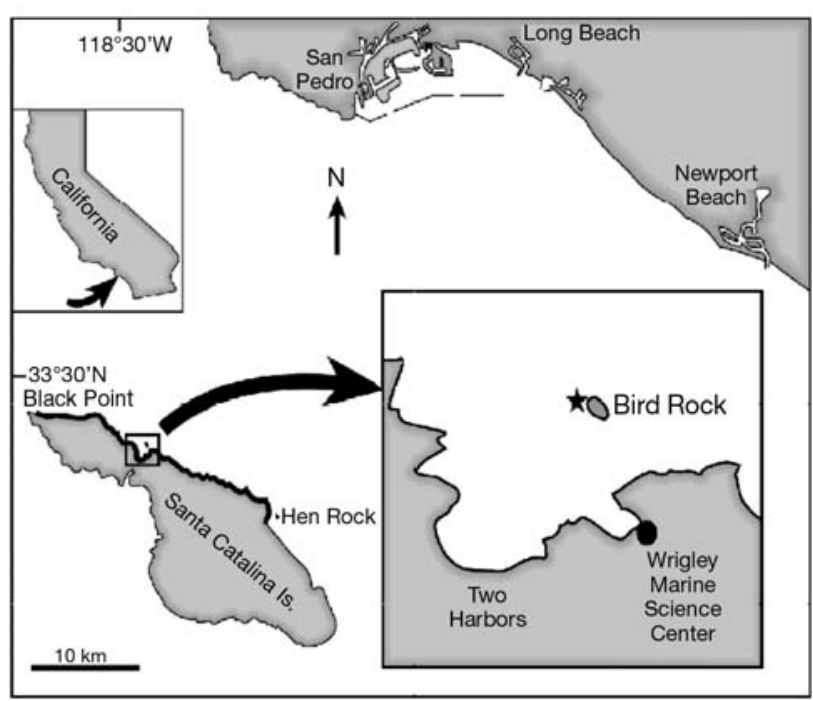

Fig. 2. The study area, near Bird Rock ( $\star)$, a small island $1 \mathrm{~km}$ offshore of the Wrigley Marine Science Center on Santa Catalina Island, $42 \mathrm{~km}$ off the coast of California. A $20-\mathrm{km}$ length along the northeast coast of Santa Catalina (in bold) represents the larger-scale area surveyed for Eisenia arborea, Corynactis californica and associated macroalgae

To determine whether the abundance of functional groups varied between canopy and open habitats, data were pooled, and percentages arcsin transformed and analyzed with a 1-way ANOVA.

Corynactis californica abundance was quantified on a larger scale along the northeast coast of Santa Catalina Island from Black Point to Hen Rock (19.8 km, Fig. 2), where the prevailing swell conditions are similar to the principal study site, Bird Rock. Twenty sites (area $\approx 1050 \mathrm{~m}^{2}$ per site) were surveyed over 1 mo for abundance of (1) C. Californica polyps; (2) Eisenia arborea individuals; and (3) macroalgae under the E. arborea canopy if present, and in open habitats. At each site a $35 \mathrm{~m}$ transect line was run along the seaward edge of the E. arborea canopy, distinguishing the canopy and open habitats. Ten $0.0625 \mathrm{~m}^{2}$ quadrats were placed within each habitat using a random number generator to select points along the transect line and the number of fin-kicks into each habitat. To determine whether $C$. californica densities varied between the 2 habitats at each site and between sites, square-root-transformed data were analyzed with a 2-way ANOVA.

To test the hypothesis that the percent cover of understory macroalgae facilitates a greater abundance of Corynactis californica in canopy habitats than open areas, permanent $0.0625 \mathrm{~m}^{2}$ quadrats were established haphazardly in the canopy and open habitats at Bird Rock (Fig. 1). Each quadrat was designated by 2 masonry nails at opposite corners and a numbered alu- minum tag. Three macroalgal treatments ( $\mathrm{n}=10$ per treatment) were established in each habitat: (1) a complete removal of all understory algae; (2) random thinning of understory algae by removing $50 \%$ cover; and (3) a control with no algal removal. If the interaction between understory algae and C. californica was competitive, it was hypothesized that $C$. californica populations would increase when macroalgae was removed (Treatment 1) in comparison to the other treatments. Conversely, if the interaction were positive then C. californica populations would increase when macroalgae was present (Treatment 3, control). Degrees of positive and/or negative effects of understory algae were addressed in the thinning treatment (Treatment 2). For example, a dense population of macroalgae might inhibit C. californica population growth through space evasion, abrasion, and increased sediment deposition. However, a thinned population of macroalgae might facilitate $C$. californica abundance by supporting larval settlement, particle capture success, and providing protection from harsh wave action. Macroalgae were removed carefully at the holdfast between $C$. californica polyps using forceps. Random thinning was accomplished by using a numbered quadrat subdivided into 25 squares. Twelve pairs of coordinates were generated for each thinned quadrat and macroalgae was removed from those 12 squares each month to maintain consistency in plot maintenance.

All treatments were censused monthly for the number of Corynactis californica polyps present from August 2004 through February 2005 and every 2 mo from April 2005 through July 2005. Initial measurements of polyp diameter and the distance from a polyp to a nearest neighbor did not vary within canopy and open habitats. A quadrat subdivided into 25 squares was used to count $C$. californica polyps. To determine whether the number of $C$. californica varied between canopy and open habitats and/or algal treatments, square-root-transformed polyp abundances were analyzed using a 2-way repeated measure ANOVA with month as the repeated measure. Additionally, an a priori paired-contrast analysis combined both manipulated treatments (cleared and thinned) against the control treatment (no removal).

\section{RESULTS}

Overall, 17\% more macroalgae were quantified in the open habitat than in the canopy habitat at Bird Rock, Santa Catalina (ANOVA: $F_{1,345}=44.43, \mathrm{p}<$ 0.001 , Fig. 3b). Furthermore, the taxonomic groups of macroalgae differed greatly between the 2 habitats. Algal species were coalesced into 4 taxonomic groups broadly based on functional form: (1) foliose brown 
algae; (2) foliose/ branching red algae; (3) articulated red algae; and (4) crustose coralline algae. A greater percent cover of foliose/branching red algae was found beneath the Eisenia arborea canopy (1-way ANOVA, $F_{1,336}=16.6, \mathrm{p}<0.01$, Fig. 3a) and a greater percentage of foliose brown algae was found outside of the canopy $\left(F_{1,335}=46.8, \mathrm{p}<0.001\right.$, Fig. 3a). No significant difference among months or in the abundance of articulated coralline $(p=0.46)$ or crustose coralline algae $(p=0.53)$ was found between habitats.

Corynactis californica polyps were censused at 20 sites along the north coast of Santa Catalina Island and this species was found at 9 of the 20 sites sampled. A canopy of Eisenia arborea ranging in area from $\sim 300$ to $1200 \mathrm{~m}^{2}$ was found at all 9 of these sites. Of the remaining 11 sites, 7 had E. arborea canopies and 4 had no canopy. Where C. californica was found, a greater density of polyps was found consistently under the $E$. arborea canopy than outside (2-way ANOVA, $\left.F_{1,8}=15.04, \mathrm{p}<0.001\right)$. These survey results indicate that the E. arborea habitat is common at Santa Catalina Island and that the pattern of increased abundance of C. californica in canopy habitats is a general feature.

Long-term sampling of Corynactis californica aggregations within permanent quadrats in the canopy and open habitats at Bird Rock also consistently demon-

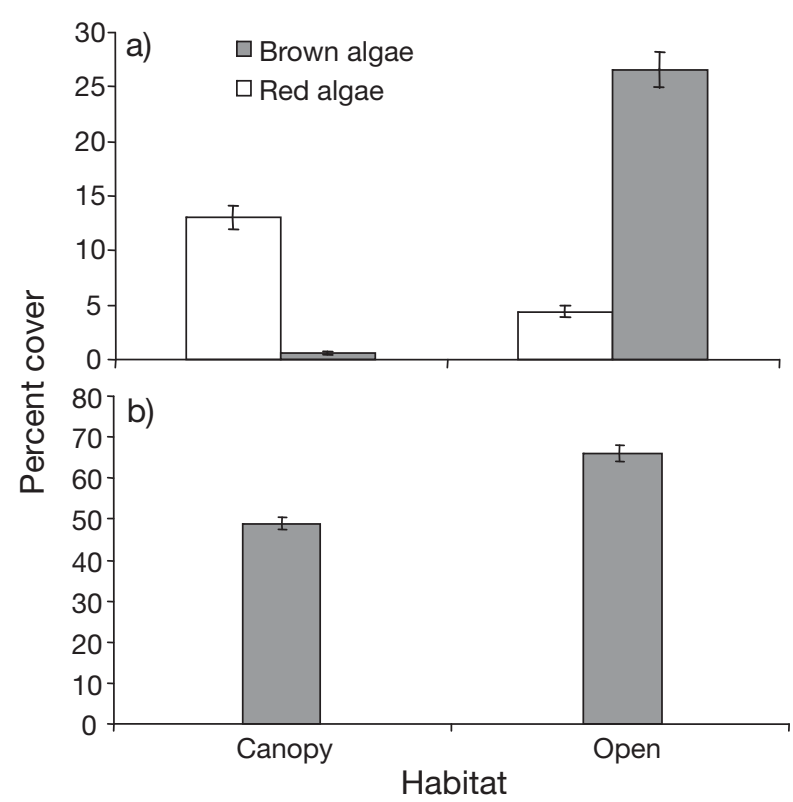

Fig. 3. (a) Mean percent cover ( $\pm \mathrm{SE}$ ) of foliose red (e.g. Chondracanthus, Gelidium, Laurencia, Plocamium, and Pterocladiella) and foliose brown algae (e.g. Colpomenia, Cystoseira, Dictyopteris, Dictyota, Halidrys, and Zonaria) found in the Eisenia arborea canopy and open habitats. (b) Mean percent cover $( \pm \mathrm{SE})$ of all macroalgae found in the canopy and open habitats. Articulated coralline algae (e.g. Bossiella, Corallina, and Lithothrix) make up the additional percentage not represented in (a). $\mathrm{N}=6$ sampling periods over $1 \mathrm{yr}$ strated a greater abundance of polyps under Eisenia arborea than outside $\left(F_{1,29}=109.65, \mathrm{p}<0.001\right.$, Table 1$)$. The average density $( \pm \mathrm{SE})$ of $C$. californica in control plots ranged from $50 \pm 9$ polyps per quadrat in the open habitat to $183 \pm 36$ polyps per quadrat under the canopy ( $\mathrm{n}=9$ ). At times, up to a 4 -fold difference in the abundance of polyps was found between the 2 habitats (Fig. 4a); however, temporal variability was high among sample periods (Fig. 4b). The majority of quadrats maintained a consistent population or increased in polyp density over time and at least 11 quadrats doubled their numbers in $<2$ mo. Conversely, the few quadrats that decreased in polyp density occurred more frequently in cleared and thinned treatments. Within-factor analysis for sampling months $(\mathrm{n}=9)$ failed to meet Mauchly's test of sphericity ( $p<0.001)$; therefore, the Huyn-Feldt epsilon (HF) sphericity adjustment was applied to compute adjusted $F$-values. Regardless of sphericity adjustments, results indicated a significant month-by-algal treatment interaction (repeated measures ANOVA, $F_{16,232}=1.822, \mathrm{p}=0.034$, Table 1). C. californica abundance was consistently higher in the control treatments in both habitats (Fig. 4b). An a priori paired contrast in which the 2 manipulated treatments (cleared and thinned) were compared against the control treatment revealed a stronger positive relationship $\left(F_{1,28}=5.01, \mathrm{p}=0.03\right.$, Table 1) where the control treatment had a higher density of polyps than the manipulated treatments. Graph-

Table 1. Corynactis californica. Two-way repeated measures ANOVA of square-root transformed data. Within subject data are presented with the Huyn-Feldt epsilon (HF) sphericity adjustment. Between-subject HF adjusted results did not significantly vary from reported results. Month was treated as a repeated measure $(n=9)$. The 3 treatments were (1) complete algal removal; (2) algal thinning; and (3) no removal (control). A priori paired contrast between control (3) and manipulated treatments, (1) and (2). Significant values are shown in bold

\begin{tabular}{|lcccc|}
\hline & df & MS & F-ratio & $\mathrm{p}$ \\
\hline Repeated measures ANOVA & & & \\
Between subjects & & & & \\
$\quad$ Habitat & 1 & 2705.6 & 109.65 & $<\mathbf{0 . 0 0 1}$ \\
Treatment & 2 & 62.75 & 2.543 & 0.09 \\
Habitat $\times$ Treatment & 2 & 0.148 & 0.006 & 0.99 \\
Error & 29 & 24.68 & & \\
Within subjects & & & & \\
$\quad$ Month & 7 & 8.302 & 6.275 & $<\mathbf{0 . 0 0 2}$ \\
Month $\times$ Habitat & 7 & 2.897 & 2.19 & $\mathbf{0 . 0 3 4}$ \\
Month $\times$ Treatment & 15 & 2.41 & 1.822 & $\mathbf{0 . 0 3 4}$ \\
$\quad$ Month $\times$ Habitat $\times$ & 15 & 0.833 & 0.63 & 0.846 \\
$\quad$ Treatment & 232 & 1.213 & & \\
Error & & & & \\
A priori paired contrast & 1 & 50.6635 & 5.01 & $\mathbf{0 . 0 3}$ \\
\hline
\end{tabular}




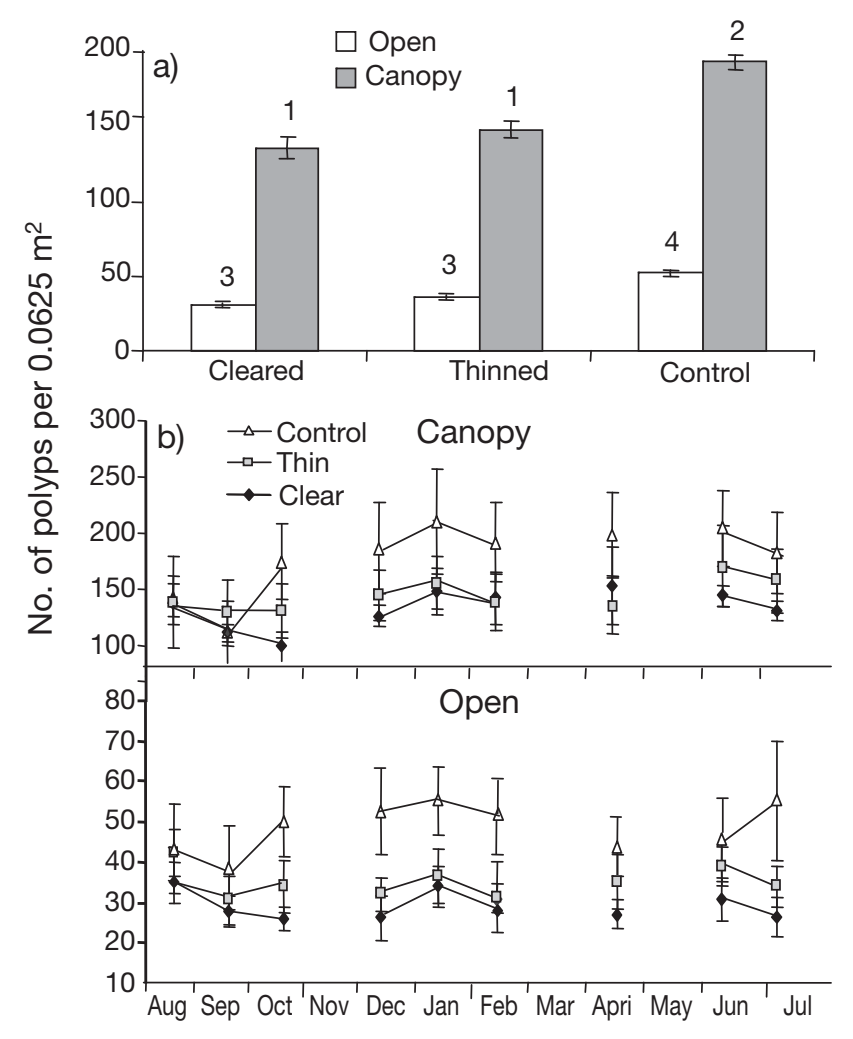

Fig. 4. (a) Mean abundance $( \pm \mathrm{SE})$ of Corynactis californica polyps per $25 \mathrm{~cm} \times 25 \mathrm{~cm}$ quadrat $\left(0.0625 \mathrm{~m}^{2}\right)$ from October (initial detection of treatment effect) through July ( $\mathrm{n}=7$ sampling periods). Quadrats were averaged to yield a grand mean per treatment (cleared, thinned, control) and habitat (open and canopy). 1-4 represent statistical differences based on a priori analysis $(\mathrm{p}<0.05)$. (b) Mean abundance $( \pm \mathrm{SE})$ of C. californica polyps each month over $1 \mathrm{yr}$ in each canopy habitat $(\mathrm{n}=10)$

ical analyses indicated that the effect of algal treatment could not be detected fully within the sample plots until the third month (October 2004). Finally, there was a significant month-by-habitat effect which indicated that the absolute number of polyps in all treatment plots varied between habitats over time (repeated measures ANOVA, $F_{8,232}=2.190, \mathrm{p}_{\mathrm{HF}}=$ 0.034, Table 1).

To examine the cause of variation between habitats in relation to Corynactis californica abundance over time, a post hoc analysis of slopes (number of polyps vs. time), statistically compared all treatments and sampling months starting in October, when the treatment effect was first detected. Slopes were generated for each quadrat using percent change in polyp number and sampling month. The percent change was calculated as the number of polyps per quadrat divided by the initial number of polyps sampled (August) multiplied by 100 . The percentage change removed the confounding difference in densities between habitats. The average slope under the canopy $(b=4.4 \pm 0.7)$ was approximately twice that exhibited in the open habitat $(b=2.7 \pm 1.9)$, suggesting that $C$. californica populations grew faster under the canopy. However, these 2 slopes are indistinguishable statistically and without further field manipulation interpretation remains speculative (ANOVA: $F_{1,33}=0.496, \mathrm{p}=0.486$ ).

\section{DISCUSSION}

This study examined 2 habitats within a southern California kelp forest distinguished by the presence or absence of the stipitate kelp Eisenia arborea to gain insight into the complex associations that develop between sessile invertebrates and foliose macroalgae within these habitats. Aggregations of Corynactis californica were found in greater densities under E. arborea canopies than just outside them and we hypothesized that varying macroalgal densities between canopy and open habitats were driving this distribution of polyps. Manipulative algal experiments indicated that understory algae might facilitate C. californica abundance to variable degrees in both habitats. Over a longer study period, C. californica populations may exhibit faster growth rates within the canopy habitat, suggesting that the strength of the positive algal interaction is greater under the canopy. The community of macroalgae found beneath the canopy has $17 \%$ less macroalgae and a significantly different composition than the assemblage found in the open habitat. This study demonstrates how small-scale interactions that occur among benthic invertebrates and algal assemblages essentially are nested within, and dependent upon, larger-scale positive and negative interactions created by the mediating kelp canopy.

Macroalgae did not appear to inhibit Corynactis californica in either study habitat. C. californica in control treatments, where no algae were removed, increased to densities greater than those in either algal removal treatment by the third month of the study (October 2004, Fig. 4b). C. californica consistently maintained a higher abundance in control treatments for the duration of the experiment in both habitats (Fig. 4b). However, a habitat-by-treatment interaction effect indicated that algal treatments had differential effects in the canopy versus open habitats. These results suggest that another factor, such as algal density, algal morphology and/or food delivery constraints, differs between habitats and may allow C. californica populations to expand more rapidly under the canopy than in open habitats. It also must be noted that disturbance effects from algal manipulation may have contributed to a lower abundance of $C$. californica polyps in algal 
removal treatments. However, extreme care was taken, using small metal forceps, to remove individual macroalgal thalli from between C. californica polyps. We felt that a disturbance control would not have been ecologically relevant and are confident that our results were not confounded by the act of removing the macroalgae, though it should be considered.

It was hypothesized that macroalgae facilitate Corynactis californica via several mechanisms: (1) by providing protection from predators; (2) by reducing water flow and polyp retraction; and/or (3) by increasing food and nutrient delivery. The only documented predator of C. californica polyps is the leather star Dermasterias imbricata (Annett \& Pierotti 1984). Southern California is at the extreme southern limit for $D$. imbricata and it was never observed at Santa Catalina Island. There also have been undocumented reports of predation by the bat star Asterina miniata, rare in Southern California. The single predation event observed under laboratory conditions, in which only $C$. californica tentacles were consumed, was by the nudibranch Hermissenda crassicornis. H. crassicornis was observed very rarely within the study habitat and thus it appears that predation does not have a significant effect on C. Californica populations. Secondly, macroalgae can decrease flow speeds to a level that may increase the deposition or recirculation of food particles and/or larvae out of the water column (Koehl 1996). High flow speeds can be detrimental to fully exposed cnidarian polyps by causing tentacle retraction and reduced particle capture (Patterson 1984, McFadden 1986, Anthony 1997). In addition, algal detritus may supply particulate food to suspension feeders and increase their growth rate, an effect that would be enhanced further under kelp canopies (Duggins \& Eckman 1997). Although not quantified, epifauna such as amphipods and copepods living within algal thalli could also provide another source of nutrition for C. californica polyps. C. californica is an opportunistic feeder and can absorb partially digested prey by extruding mesenterial filaments onto items too large for the coelenteron (Chadwick 1987). In another study, the complexity created by seagrass assemblages, similar to that created by macroalgae, was shown to facilitate the survival of suspension feeding bivalves (Peterson \& Heck 2001). However, both canopy and open habitats support diverse assemblages of macroalgae; therefore, a positive interaction between all macroalgae and $C$. californica does not explain fully why there are up to 4 -fold more polyps of C. Californica under Eisenia arborea canopies. The density and morphology of understory algae varied in the presence versus absence of E. arborea. One hypothesis is that $C$. californica abundance is driven by mechanisms related to the difference in algal assemblages between habitats.
Stipitate kelp such as Eisenia arborea create canopies that influence light and water flow, which in turn can have effects on understory assemblages of invertebrates, macroalgae and fishes (Kennelly 1989, Witman \& Dayton 2001, Connell 2003b, Toohey et al. 2004). Understory macroalgae were $17 \%$ less dense in E. arborea canopy habitats than in open habitats (Fig. 3). Density differences in understory algae likely are the result of ambient light levels that can be reduced up to $98 \%$ under stipitate kelp canopies (Wernberg et al. 2005, R. Carpenter unpubl. data). Light has been shown to be the primary resource limiting the growth of understory algae (Reed \& Foster 1984, Kennelly 1989, Wernberg et al. 2005). A lower density of understory algae in the canopy habitat creates more available space for the growth and recruitment of sessile invertebrates such as Corynactis californica. C. californica may compete more effectively for space under the canopy in the absence of dense macroalgal assemblages, similar to vertical rock wall habitats, by utilizing rapid asexual proliferation of aggregations as well as directly attacking encroaching invertebrates with aggressive mesenterial filaments (Chadwick 1987, Langmead \& Chadwick-Furman 1999).

However, the relative abundance of algal taxonomic groups also differs greatly between canopy and open habitats and may strongly influence polyp abundance. The majority of macroalgae outside the canopy were characterized by foliose decumbent phaeophytes (e.g. Zonaria, Dictyopteris). The majority of red algae found under the canopy were characterized by upright branching forms (e.g. Gelidium spp., Plocamium), which expose much of the underlying substratum and allow water to flow through the thalli (Anderson \& Charters 1982). Wave-driven flow has been shown to constantly move the fronds of stipitate kelp, which reduces sedimentation while scouring benthic organisms (Kennelly 1989, Connell 2003a,b). The foliose brown algal species most likely are excluded from beneath the Eisenia arborea canopy because they cannot tolerate the lower light levels or the high flow regime and resulting kelp whiplash (Kennelly 1989, Connell 2003b). Foliose red algae can acclimate to lower light levels and compete for space created by the exclusion of phaeophytes under the canopy (Reed \& Foster 1984). It also has been speculated that red algae are able to reproduce via fragmentation, which may allow them to take advantage of abrasion from sweeping E. arborea blades (Toohey et al. 2004). The hardier geniculate and non-geniculate coralline algae, which are less susceptible to dislodgement, did not vary between environments. Alternatively, the difference in algal taxonomic groups between habitats could affect particle capture and/or larval settlement, thus mediat- 
ing the distribution and abundance of Corynactis californica polyps (Eckman et al. 1989).

The positive effects of one species on another can result from several mechanisms, including the provision of a refuge from predation and physical stress while enhancing food acquisition (Witman 1987, Callaway 1995). The present study suggests that foliose and branching morphologies of understory algae influence Corynactis californica abundance through the latter 2 processes. The Eisenia arborea canopy reduces the overall density of understory algae, specifically facilitating the growth of branching red species and reducing the abundance of brown algal species. Reduced algal density beneath the canopy is likely due to increased shading and kelp whiplash. Previous physiological measurements quantified that C. californica metabolism did not vary between habitats or flow speeds (K. Morrow unpubl. data). This, coupled with the lack of observed predation, suggests that their distribution results primarily from interactions with adjacent organisms. The understory algae may facilitate particle capture and/or larval recruitment, which is critical to sustaining C. californica populations. The morphology of macroalgae may differentially alter the flow environment around C. californica polyps and increase particle capture efficiency and deposition of particles and/or larvae from the water column. Foliose species of macroalgae (found outside of the canopy) may redirect flow and food particles away from polyp tentacles while branching species (found under the canopy) may act like a mesh sieve, allowing particles to come in contact with $C$. californica tentacles more frequently (Morrow \& Carpenter 2008).

Eisenia arborea is a foundation species that mediates a diverse community of understory algae and invertebrates. Understory branching algae appear to facilitate Corynactis californica polyps to a greater degree than the foliose algae found outside of the canopy. These results help predict the types of species associations that are likely to occur under and outside of macrophyte canopies (e.g. kelp forests and seagrass beds), as well as the underlying competitive and facilitative interactions that ultimately determine the realized niche of invertebrate and algal species.

Acknowledgements. This research was supported by grants from PADI project AWARE, PADI Foundation, NIH-SCORE 506GM048680-11 (to R.C.), and in part by a grant from California State University, Northridge (CSUN). The research at Santa Catalina Island was completed with facilities support from the University of Southern California, Wrigley Institute for Environmental Studies, under permit 803037-03 from the California Department of Fish and Game. Working many long hours under the Eisenia over such a large time scale would have been impossible without the good humor and assistance of many people. In particular we thank K. Benes, R. Elahi, L. Garske, A. Hettinger, C. Morrow, G. Smith and
J. P. Williams for their field assistance. Additional thanks goes to L. Allen, N. A. Chadwick, S. Dudgeon, P. J. Edmunds, M. Steele and P. Wilson for their help in preparing this manuscript. This is Contribution No. 145 of the CSUN marine biology program.

\section{LITERATURE CITED}

Abbott IA, Hollenberg GJ (1976) Marine algae of California. Stanford University Press, Stanford, CA

Allen LG, Pondella DJ, Horn MH (2006) Ecology of marine fishes: California and adjacent waters. University of California Press, Berkeley and Los Angeles, CA

Anderson SM, Charters AC (1982) A fluid dynamics study of seawater flow through Gelidium nudifrons. Limnol Oceanogr 27:399-412

Annett C, Pierotti R (1984) Foraging behavior and prey selection of the leather sea star Dermasterias imbricata. Mar Ecol Prog Ser 14:197-206

Anthony KRN (1997) Prey capture by the sea anemone Metridium senile (L.): effects of body size, flow regime, and upstream neighbors. Biol Bull 192:73-86

Bak RPM, Borsboom JLA (1984) Allelopathic interactions between a reef coelenterate and benthic algae. Oecologia 63:194-198

Bertness MD, Leonard GH, Levine JM, Schmidt PR, Ingraham AO (1999) Testing the relative contribution of positive and negative interactions in rocky intertidal communities. Ecology 80:2711-2726

Bruno JF, Bertness MD (2001b) Habitat modification and facilitation in benthic marine communities. In: Bertness MD, Gaines SD, Hay ME (eds) Marine community ecology. Sinauer Associates, Sunderland, MA, p 201-218

Bruno JF, Stachowicz JJ, Bertness MD (2003) Inclusion of facilitation into ecological theory. Trends Ecol Evol 18: 119-125

Callaway RM (1995) Positive interactions among plants (Interpreting botanical progress). Bot Rev 61:306-349

Callaway RM, Walker LR (1997) Competition and facilitation: a synthetic approach to interactions in plant communities. Ecology 78:1958-1965

Chadwick NE (1987) Interspecific aggressive behavior of the corallimorpharian Corynactis californica (Cnidaria: Anthozoa): effects on sympatric corals and sea anemones. Biol Bull 173:110-125

Chadwick NE (1991) Spatial distribution and the effects of competition on some temperate Scleractinia and Corallimorpharia. Mar Ecol Prog Ser 70:39-48

Chadwick NE, Adams C (1991) Locomotion, asexual reproduction, and killing of corals by the corallimorpharian Corynactis californica. Hydrobiologia 216-217:263-269

- Connell JH (1983) On the prevalence and relative importance of interspecific competition: Evidence from field experiments. Am Nat 122:661-696

> Connell SD (2003a) Negative effects overpower the positive of kelp to exclude invertebrates from the understorey community. Oecologia 137:97-103

Connell SD (2003b) The monopolization of understorey habitat by subtidal encrusting coralline algae: a test of the combined effects of canopy-mediated light and sedimentation. Mar Biol 142:1065-1071

Connell JH, Slayter RO (1977) Mechanisms of succession in natural communities and their role in community stability organization. Am Nat 111:1119-1144

Connolly SR, Muko S (2003) Space preemption, size dependent competition, and the coexistance of clonal growth forms. Ecology 84:2979-2988 
Coyer JA, Ambrose RF, Engle JM, Carroll JC (1993) Interactions between corals and algae on a temperate zone rocky reef: mediation by sea urchins. J Exp Mar Biol Ecol $167: 21-37$

Dayton PK (1972) Toward and understanding of community resilience and the potential effect of enrichments to the benthos at McMurdo Sound, Antarctica. In: Parker BC (ed) Proceedings of the colloquium on conservation problems in Antarctica. Allen Press, Lawrence, KS

Duggins DO, Eckman JE (1997) Is kelp detritus a good food for suspension feeders? Effects of kelp species, age and secondary metabolites. Mar Biol 128:489-495

Eckman JE, Duggins DO, Sewell AT (1989) Ecology of understory kelp environments. I. Effects of kelp on flow and particle transport near the bottom. J Exp Mar Biol Ecol 129:173-187

Holts LJ, Beauchamp KA (1993) Sexual reproduction in the corallimorpharian sea anemone Corynactis californica in a central California kelp forest. Mar Biol 116:129-136

Hughes TP (1994) Catastrophes, phase shifts, and large-scale degradation of a Caribbean coral reef. Science 265: 1547-1551

Hutchinson GE (1961) The paradox of the plankton. Am Nat 95:137-145

Irving AD, Connell SD (2002) Sedimentation and light penetration interact to maintain heterogeneity of subtidal habitats: algal versus invertebrate dominated assemblages. Mar Ecol Prog Ser 245:83-91

Irving AD, Connell SD (2006) Physical disturbance by kelp abrades erect algae from the understorey. Mar Ecol Prog Ser 324:127-137

> Jackson JBC (1977) Competition on marine hard substrata: the adaptive significance of solitary and colonial strategies. Am Nat 111:743-767

Jompa J, McCook LJ (2002) Effects of competition and herbivory on interactions between a hard coral and a brown alga. J Exp Mar Biol Ecol 271:25-39

Kennelly SJ (1987a) Physical disturbances in an Australian kelp community. I. Temporal effects. Mar Ecol Prog Ser 40:145-153

Kennelly SJ (1987b) Physical disturbances in an Australian kelp community. II. Effects on understorey species due to differences in kelp cover. Mar Ecol Prog Ser 40:155-165

Kennelly SJ (1989) Effects of kelp canopies on understorey species due to shade and scour. Mar Ecol Prog Ser 50: 215-224

Koehl MAR (1996) When does morphology matter? Annu Rev Ecol Syst 27:501-542

LaJeunesse TC, Bhagooli R, Hidaka M, deVantier L and others (2004) Closely related Symbiodinium spp. differ in relative dominance in coral reef host communities across environmental, latitudinal, and biogeographic gradients. Mar Ecol Prog Ser 284:147-161

Langmead O, Chadwick-Furman NE (1999) Marginal tentacles of corallimorpharian Rhodactis rhodostoma. 2. In-

Editorial responsibility: Kenneth Heck, Dauphin Island, Alabama, USA duced development and long-term effects on coral competitors. Mar Biol 134:491-500

Littler DS, Littler MM (1997) Epizoic red alga allelopathic (?) to a Caribbean coral. Coral Reefs 16:168

McCook LJ, Jompa J, Diaz-Pulido G (2001) Competition between corals and algae on coral reefs: a review of evidence and mechanisms. Coral Reefs 19:400-417

McFadden CS (1986) Colony fission increases particle capture rates of a soft coral: advantages of being a small colony. J Exp Mar Biol Ecol 103:1-20

McManus JW, Polsenberg JF (2004) Coral-algal phase shifts on coral reefs: ecological and environmental aspects. Prog Oceanogr 60:263-279

Morrow KM, Carpenter RC (2008) Effects of macroalgal thallus morphology on rates of particle capture by the corallimorpharian Corynactis californica. Mar Biol (in press)

Patterson M (1984) Patterns of whole colony prey capture in the octocoral, Alcyonium siderium. Biol Bull 167:613-629

Patton ML, Brown ST, Harman RF, Grove RS (1991) Effect of the anemone Corynactis californica on subtidal predation by the sea stars in the southern Califonia bight. Bull Mar Sci 48:623-634

> Peterson BJ, Heck KL Jr (2001) Positive interactions between suspension-feeding bivalves and seagrass-facultative mutualism. Mar Ecol Prog Ser 213:143-155

Reed DC, Foster MS (1984) The effects of canopy shading on algal recruitment and growth in a giant kelp forest. Ecology 65:937-948

Sebens KP (1982) Asexual reproduction in Anthopleura elegantissima (Anthozoa: Actinaria): seasonality and spatial extent of clones. Ecology 63:434-444

Taylor PR, Littler MM (1982) The roles of compensatory mortality, physical disturbance, and substrate retention in the development and organization of a sand-influenced, rocky intertidal community. Ecology 63:135-146

Toohey B, Kendrick GA, Wernberg T, Phillips JC, Malkin S, Prince J (2004) The effect of light and thallus scour from Ecklonia radiata canopy on an associated foliose algal assemblage: the importance of photoacclimation. Mar Biol 144:1019-1027

Travis JMJ, Brooker RW, Dytham C (2004) The interplay of positive and negative interactions across an environmental gradient: insights from an individual based simulation model. Biol Lett 1:5-8

Wernberg T, Kendrick GA, Toohey BD (2005) Modification of the physical environment by Ecklonia radiata (Laminariales) canopy and implications for associated foliose algae. Aquat Ecol 39:419-430

Witman JD (1987) Subtidal coexistence: storms, grazing, mutualism, and the zonation of kelps and mussels. Ecol Monogr 57:167-187

Witman JD, Dayton PK (2001) Rocky subtidal communities. In: Bertness MD, Gaines SD, Hay ME (eds) Marine community ecology. Sinauer Associates, Sunderland, MA, p 339-361

Submitted: October 28, 2006; Accepted: December 10, 2007 Proofs received from author(s): May 20, 2008 